\title{
TAND Checklist - a new tool for assessment of neuropsychiatric disorders in tuberous sclerosis patients
}

\section{Lista kontrolna TAND - nowe narzędzie do badania zaburzeń neuropsychiatrycznych u pacjentów ze stwardnieniem guzowatym}

\author{
Agata Siłuszyk1 (iD), Agnieszka Maryniak² (D), Sergiusz Jóźwiak1,3 (iD) \\ 'Department of Pediatric Neurology. Warsaw Medical University, Warsaw, Poland \\ ${ }^{2}$ Faculty of Psychology, University of Warsaw, Warsaw, Poland \\ ${ }^{3}$ Department of Neurology and Epileptology, The Children's Memorial Health Institute, Warsaw, Poland. \\ DOI:10.20966/chn.2018.54.421
}

\section{ABSTRACT}

Tuberous sclerosis complex (TSC) is a rare genetic disorder which manifests itself in abnormalities in the structure and functioning of many organs such as brain, heart, liver, kidneys. Besides, patients with TSC have a range of cognitive, psychological and psychiatric difficulties that collectively are called TAND (TSC Associated Neuropsychiatric Disorders). The surveys showed that most patients with TSC experience several disturbances during their lifetime, nevertheless the majority do not receive the help they need. To facilitate To facilitate specialists to monitor the TAND symptoms, in 2015 de Vries and colleagues developed TAND Checklist which has now been translated into Polish. In the article we discuss the main dysfunctions of patients, describe the structure of the questionnaire and present the preliminary results of the validation of the tool translated into Polish. Key words: tuberous sclerosis complex, TAND, psychiatric disorders, neuropsychological deficits

\section{STRESZCZENIE}

Stwardnienie guzowate (TSC) jest rzadką chorobą genetyczną, która przejawia się nieprawidłowościami w budowie i funkcjonowaniu wielu narządów, takich jak mózg, serce, wątroba, nerki. Ponadto pacjenci z TSC mają szereg zaburzeń poznawczych, psychologicznych i psychiatrycznych, które zbiorczo nazywa się trudnościami TAND (Tuberous Sclerosis Associated Neuropsychiatric Disorders). Badania pokazują, że większość pacjentów z TSC doświadcza kilku zaburzeń w ciągu życia, niemniej jednak większość z nich nie otrzymuje potrzebnego wsparcia. Aby ułatwić specjalistom możliwość monitorowania objawów TAND, w 2015r. de Vries i wspótpracownicy stworzyli kwestionariusz (TAND Checklist), który obecnie został przetłumaczony również na język polski. W niniejszej pracy omówione zostały główne zaburzenia osób z TSC, a także opisano budowę kwestionariusza TAND i przedstawiono wstępne wyniki walidacji przetłumaczonego narzędzia.

Słowa kluczowe: stwardnienie guzowate, TAND, zaburzenia psychiatryczne, deficyty neuropoznawcze

\section{INTRODUCTION}

Tuberous sclerosis complex (TSC) is a genetic disorder with a prevalence of 1:6000 births [1]. In $85 \%$ of the cases a mutation in a gene TSC1 (chromosome 9q34) or TSC2 (chromosome 16p13.3) is recognized. The genes code proteins - hamartin and tuberin respectively [2, 3], which inhibit the mTOR (mammalian target of rapamycin) pathway, are responsible for the regulation of the process of cell maturation and differentiation [4]. Mutations in the TSC1 or TSC 2 genes result in disinhibition of the mTOR pathway, what in turn leads to the formation of tumors in many organs $[5,6]$. In the $2 / 3$ of patients mutations arise spontaneously (de novo), while in the remaining $1 / 3$ they are inherited [3, 7].

There is a big variety in clinical manifestations of the syndrome. The main symptoms can include skin lesions, tumors in central nervous system (CNS), tumors of heart, kidneys, lungs, and eyes [8-10]. Around $70-90 \%$ of patients have epilepsy which in most cases appears in the first year of life [11-13]. The diagnosis of TSC is primarily based on clinical symptoms, but the new criteria allow to make a diagnosis only in virtue of genetic testing, even if no other clinical manifestations are observed [14].

\section{NEUROPSYCHOLOGICAL AND PSYCHIATRIC DYSFUNCTIONS}

Next to the tendency to the formation of tumors, patients with TSC very often have neuropsychological and psychiatric problems. Nearly $30 \%$ of them are diagnosed with profound intellectual disability, while other $20 \%$ suffer from mild or moderate intellectual disability [7, 15]. Although the remaining half of patients are developing within the intellectual norm, most of them have some neurodevelopmental deficits [16]. For example, children with TSC who are not impaired still obtain statistically significant lower scores in the intelligence tests (mean IQ 94) as compared to their healthy siblings (mean IQ 106) [7].

Similarly, around half of patients are at risk of developing autism spectrum disorder. That makes the TSC one of 
the genetic diseases with the highest risk of developing autism $[17,18]$. Also, attention-deficit hyperactivity disorder (ADHD) occurs more frequently than in general population $(30-50 \%)[19-21]$, the same as depression and anxiety disorders (30-60\%) [22-24].

Moreover, people with TSC often have behavioral problems, such as aggressive outbursts [25, 26], temper tantrums [25] and self-injury [26, 27]. Many patients have difficulties with concentration [28], memory [29] and executive skills [19]. It is also common that they have low self-esteem and experience high level of stress in the family [30]. There is a high possibility that many patients have delayed speech development or language impairment, but there has been no research done on this topic so far. All these difficulties may affect the functioning at school and work.

The presence of structural defects in the brain and seizure activity in EEG are given as the reason for the occurrence of the disturbances and neurological deficits. Also, the appearance of a sick person in the family can generate a high level of stress, which affects the functioning of the entire family system. Increasingly, however, it is said that the hyperactivity of the mTOR pathway may be a direct cause of some cognitive impairment $[16,31]$. This seems to be confirmed by animal studies that showed mice with mutations in the TSC1 and TSC2 genes, which did not have any abnormalities in the structure of the brain and did not present epileptic seizures, nevertheless manifested cognitive and social deficits $[32,33]$.

\section{THE CONCEPT OF TAND}

The difficulties mentioned above are classified as behavioral disturbances, psychiatric disorders, intellectual disabilities, school problems, neuropsychological deficits and psychosocial disorders [34]. Due to the variety of terminology used to describe the problem it has been proposed during the Neuropsychiatry Panel at the 2012 Tuberous Sclerosis Complex International Consensus Conference to establish the term of TAND (TSC-Associated-NeuropsychiatricDisorders) [35]. The authors of the concept emphasize that the new definition is not to imply that all the levels of functioning are similar. It is to create an "umbrella term" under which all mentioned areas would be placed [34]. The name can clarify terminology and it can help to increase the awareness of patients, their families and specialists about the occurrence of given problems.

The new term refers to the existing HAND concept (HIV-Associated-Neuropsychiatric-Disorders). It was created because people struggling with HIV noticed that however psychological and psychiatric problems are very common among them, they rarely receive support in this area. Due to the somatic dysfunctions caused by the action of the virus, these patients are provided with a wide diagnosis and treatment of physical symptoms, but it is often forgotten that disease is also reflected in the mental functioning. A similar situation is observed in patients with TSC. Because the disease attacks many organs, patients are forced to frequent visits in various hospital wards, yet, their psychological functioning is often overlooked. This is also confirmed by surveys which showed that while $90 \%$ of people with TSC throughout their lifetime develop difficulties in the TAND group, only $20 \%$ of them receive the necessary diagnosis and therapeutic support [36].

Due to the gap in the field of mental health of people with TSC, during the conference in 2012, a recommendation was made to monitor at least once a year the occurrence of TAND symptoms [35]. To facilitate this task, de Vries and colleagues created TAND Checklist [34]. The role of the questionnaire is to help create a list of symptoms that concern the most patients and their families. It may also help to create intervention plan for the family. This may involve referring the person to additional diagnostic tests to specialist counseling, explaining the mechanism of difficulties or giving information about therapeutic centers that deal with a given problem.

\section{THE STRUCTURE OF TAND CHECKLIST}

The original questionnaire was written in English and is available in a free access. It has a form of a structured interview carried out by a specialist (doctor, psychologist) with a parent or, if possible, directly with the patient. This tool has no age limits - it can be used to assess both small children, adolescents and adults. It does not include a rating scale allowing to determine a severity of a given feature. Most questions require only a simple answer "Yes" (a given difficulty occurs) - "No" (does not occur).

The tool consists of twelve parts, each refers to a different functional area. In the first section there are questions about the age of occurrence of basic milestones. This allows to evaluate the development in the first years of life. The next questions (second part) refer to the current functioning of the person: the degree of language development, motor skills and self-service activities.

The third part contains questions on whether the individual has ever had particular behavioral difficulties. These are such behaviors as: high anxiety, depressive mood, mood swings, aggressive outbursts, temper tantrums, difficulty paying attention, social and communication difficulties (delayed speech development, poor eye contact, difficulties getting on with peers), rigid and inflexible behaviors, difficulties with eating or sleep.

In the next section (fourth) it is asked if the person has been diagnosed with most common disorders in TSC as defined by the DSM-V or ICD-10 classifications. These are such disorders as: autism spectrum disorder, ADHD, anxiety disorders, depression, obsessive-compulsive disorder (OCD) and psychotic disorders (including schizophrenia).

The fifth part focuses on the assessment of the intellectual abilities. This section deals with questions whether the person was diagnosed using standardized IQ tests, and if so, how its development was classified. In addition, parents are asked about their own opinion about their child intellectual level as many patients with TSC have never had an IQ test, and because it is possible that the scores of such tests can be different than the observed level of skills [34].

The next section (sixth) tries to asses if the person has problems with school abilities such as reading, writing, spelling and mathematics, whereas the seventh part identi- 
Tab. I. Characteristics of questions in the TAND Checklist

Tab. I. Charakterystyka pytań Listy Kontrolnej TAND

\begin{tabular}{cll}
\hline Question number & \multicolumn{1}{c}{ What denotes? } & \multicolumn{1}{c}{ Who responds? } \\
\hline Question 1 & Basic developmental milestones & Parent/ caregiver/ patient \\
\hline Question 2 & Current level of functioning & Parent/ caregiver/ patient \\
\hline Question 3 & Behavioral disturbances & Parent/ caregiver/ patient \\
\hline Question 4 & Psychiatric disorders diagnosed & Parent/ caregiver/ patient \\
\hline Question 5 & Intellectual level & Parent/ caregiver/ patient \\
\hline Question 6 & Academic skills & Parent/ caregiver/ patient \\
\hline Question 7 & Neuropsychological skills & Parent/ caregiver/ patient \\
\hline Question 8 & Psychosocial functioning & Parent/ caregiver/ patient \\
\hline Question 9 & Parent, caregiver, or self-rating & Parent/ caregiver/ patient \\
\hline of the impact of TAND & \\
\hline Question 10 & Prioritizing list & Parent/ caregiver/ patient \\
\hline Question 11 12 & Additional concerns & Parent/ caregiver/ patient \\
\hline & Health-care professional rating & Specialist (doctor/ psychologist) \\
\hline
\end{tabular}

fies neuropsychological deficits. These can be: difficulties with memorizing, concentration, dual-tasking, visual-spatial skills, executive functions (planning, organizing, flexible thinking, decision making).

In the psychosocial area (eighth section) the important determinants of the quality of life are examined. There are questions indicating if person has low self-esteem, difficulties in relationships between family members (e.g. siblings) and difficulties associated with high level of stress between parents.

In the ninth part respondents are asked how much the mentioned problems disturb them. Questions tenth and eleventh may help in prioritizing problems and in showing those disturbances which were not mentioned in questionnaire. The last question (twelfth) is addressed to specialists who are asked about the impact of TAND on the person and the family. According to the authors of the tool, the differences between the opinion of parents/patients and the opinions of specialists can be a result of underestimation or overestimation of the problem by the family [34]. The characteristics of questions in the TAND Checklist are presented in Table I.

It is worth mentioning that during the validation of the original version of the questionnaire, specialists and parents/caregivers from 28 countries were asked for the opinion [36]. They found TAND Checklist as clear, understanding, comprehensive and easy in use. Statistical analysis of the item showed from very good to excellent internal consistency. There was also a high correlation with tests measuring the general symptoms of mental disorders (the Strengths and Difficulties Questionnaire), behaviors related to the autism spectrum (the Social-Communication Questionnaire), disability (the Wessex Rating Scale) and executive functions (the Behavior Rating Inventory of Executive Functions).

\section{THE POLISH VERSION OF THE TAND CHECKLIST}

The Polish adaptation of the questionnaire was carried out with the permission of the authors of the scale. The translation of the positions into Polish was made by prof. Agnieszka Maryniak and prof. Sergiusz Jóźwiak. The Polish language version contains all the questions that are contained in the original version. ${ }^{1}$

The pre-pilot validation of the Polish version of Checklist was carried out involving 13 parents of children aged 20 months-15 years (average age 7 years). Patient interviews were conducted by a psychologist at the Department of Pediatric Neurology of the Medical University of Warsaw and during the Annual Meeting of Polish Tuberous Sclerosis Association in 2018. Then, parents were asked to complete a survey evaluating the questionnaire.

All parents (15) stated that the questions in the TAND Checklist are understandable. The usefulness of the tool was evaluated on the 5-point scale, where: 1 - useless, 2 not very useful, 3 - a little useful, 4 - useful, 5 - very useful. The average parents' rating was 4.3 so the tool was found useful by them. Only two parent pointed out that no difficulties affected his child, the rest of the parents $(87 \%)$ acknowledged difficulties in their children's behavior, indicating in each case the occurrence of more than one problem. In addition, one parent pointed out that the questionnaire should contain more detailed questions, while the other parents stated that the questions were comprehensive.

\section{SUMMARY}

The aim of the new concept of TAND is to increase the awareness of the psychological and psychiatric difficulties common among patients with TSC. Due to the fact that TSC carries a lot of somatic symptoms, the health care provides support mainly in this area. It is worth remembering,

\footnotetext{
${ }^{1}$ Questionnaire is available from the first author on request
} 
however, that families who learned about child's disease are in a stressful situation and they need psychological support. They also require extensive support later, as well as the attention to their problems and information on the sources and forms of possible help. The TAND Checklist established in 2015 is meant to fulfill these criteria. Its role is to monitor the problems of mental health and help to draw up an intervention plan for patients and their families.

Due to the good reception in the English-speaking countries, the questionnaire was translated into Polish. Our pre-pilot validation showed that it is also well perceived by Polish parents who believe that the questionnaire is useful, comprehensive and understandable. The analysis also showed that $87 \%$ of the examined children exhibited psychological and psychiatric difficulties, which confirms the importance of studying mental functioning of the patients with TSC.

The questionnaire is de facto an interview with a patient or his/her parents/caregivers, which enables the tool to be even more detailed. On the one hand, it can help parents/patients discover the symptoms experienced by the patients. On the other hand, it allows the specialists to understand the patient's difficulties and needs better. Furthermore, the annual repetition of the interview helps to provide a quicker reaction in case of any new dysfunctions. This is particularly important as sometimes changes in the mental functioning may indicate somatic changes, especially the appearance of SEGA (subependymal giant-cell astrocytoma), deterioration of the EEG, the impact of side effects of drugs [21].

A further research examining the usefulness of the Polish version of TAND Checklist is needed. Our pre-pilot validation is based on the small research sample and the opinion of other patients, parents and specialists would be valuable. Nevertheless, both validation of the English version of the tool and our research demonstrated that the tool is well perceived. It can be assumed that the questionnaire facilitates the monitoring of TAND and responds to patients' needs.

\section{ACKNOWLEDGEMENTS}

Agata Siłuszyk was supported by the grant EPIMARKER of the Polish National Center for Research and Development No STRATEGMED3/306306/4/2016.

Sergiusz Jóźwiak was partly supported by the European Community's Seventh Framework Programme (FP7/2007-2013; EPISTOP, grant agreement no. 602391), the Polish Ministerial funds for science (years 20132019) for the implementation of international co-financed project and the grant EPIMARKER of the Polish National Center for Research and Development No STRATEGMED3/306306/4/2016.

\section{LIST OF ABBREVIATIONS}

TAND - TSC-Associated-Neuropsychiatric-Disorders

TSC - tuberous sclerosis complex

mTOR - mammalian target of rapamycin

ADHD - attention-deficit hyperactivity disorder

EEG - electroencephalography
DSM-V - The Diagnostic and Statistical Manual of Mental Disorders, Fifth Edition

ICD-10 - International Statistical Classification of Diseases and Related Health Problems

SEGA - subependymal giant-cell astrocytoma

\section{REFERENCES}

[1] Napolioni, V., Curatolo, P.: Genetics and molecular biology of tuberous sclerosis complex. Curr Genomics 2008; 9: 475-487.

[2] Juelich, K., Sahin, M.: Mechanism-based treatment in tuberous sclerosis complex. Pediatr Neurol 2014; 50: 290-296.

[3] Curatolo, P., Bombardieri, R., Jóźwiak, S.: Tuberous sclerosis. Lancet 2008; 372: 657-668.

[4] Dębkowska, A. E., Jóźwiak, S.: Dysregulation of mTOR pathway and role of the rapamycine and its derivatives in treatment of neurological disorders. Child Neurol 2015; 48: 9-13.

[5] Tee, A. R., Fingar, D. C., Manning, B. D., et al.: Tuberous sclerosis complex-1 and-2 gene products function together to inhibit mammalian target of rapamycin (mTOR)-mediated downstream signaling. Proc Natl Acad Sci 2002; 99: 13571-13576.

[6] Tee, A. R., Manning, B. D., Roux, et al.: Tuberous sclerosis complex gene products, Tuberin and Hamartin, control mTOR signaling by acting as a GTPase-activating protein complex toward Rheb. Curr Biol 2003; 13: 1259-1268.

[7] Joinson, C., O,Callaghan, F. J., Osborne, J. P., et al.: Learning disability and epilepsy in an epidemiological sample of individuals with tuberous sclerosis complex. Psychol Med 2003; 33: 335-344.

[8 Northrup, H., Koenig, M. K., Au, K. S.: Tuberous sclerosis complex. [in:] GeneReviews. Pagon, R. A., Adam, M. P. Ardinger, H. H., et al [ed.], University of Washington, Seattle 2015.

[9 Curatolo, P., Maria, B. L.: Tuberous sclerosis. Handb Clin Neurol 2013; 111: 323-331.

[10 Leung, A. K., Robson, W. L. M.: Tuberous sclerosis complex: a review. J Pediatr Health Care 2007; 21: 108-114.

[11] Chu-Shore, C. J., Major, P., Camposano, S., et al.: The natural history of epilepsy in tuberous sclerosis complex. Epilepsia 2010; 51: 1236-1241.

[12] Wu, J. Y., Peters, J. M., Goyal, M., et al.: Clinical electroencephalographic biomarker for impending epilepsy in asymptomatic tuberous sclerosis complex infants. Pediatr Neurol 2016; 54: 29-34.

[13] Curatolo, P., Jóźwiak, S., Nabbout, R.: Management of epilepsy associated with tuberous sclerosis complex (TSC): clinical recommendations. Eur J Paediatr Neurol 2012; 16: 582-586.

[14] Northrup, H., Krueger, D. A., Roberds, S., et al: Tuberous sclerosis complex diagnostic criteria update: recommendations of the 2012 International Tuberous Sclerosis Complex Consensus Conference. Pediatr Neurol 2013; 49: 243-254.

[15] de Vries, P. J., Prather, P. A.: The tuberous sclerosis complex. N Engl J Med 2007; 356: 93-94.

[16] de Vries, P. J.: Targeted treatments for cognitive and neurodevelopmental disorders in tuberous sclerosis complex. Neurotherapeutics 2010; 7: 275-282.

[17] Bolton, P. F., Park, R. J., Higgins, J. N. P., et al.: Neuro-epileptic determinants of autism spectrum disorders in tuberous sclerosis complex. Brain 2002; 125: 1247-1255.

[18] Numis, A. L., Major, P., Montenegro, M. A., et al.: Identification of risk factors for autism spectrum disorders in tuberous sclerosis complex. Neurology 2011; 76: 981-987.

[19] Prather, P., de Vries, P. J.: Behavioral and cognitive aspects of tuberous sclerosis complex. J Child Neurol 2004; 19: 666-674.

[20] Muzykewicz, D. A., Newberry, P., Danforth, N., et al.: Psychiatric comorbid conditions in a clinic population of 241 patients with tuberous sclerosis complex. Epilepsy Behav 2007; 11: 506-513.

[21] Leclezio, L., de Vries, P.: Towards an improved understanding of TSCAssociated Neuropsychiatric Disorders (TAND). Advances in Autism 2016; 2: 76-83.

[22] Lewis, J. C., Thomas, H. V., Murphy, K. C., et al.: Genotype and psychological phenotype in tuberous sclerosis. J Med Genet 2004; 41: 203-207.

[23] Raznahan, A., Joinson, C., O'Callaghan, F., et al.: Psychopathology in tuberous sclerosis: an overview and findings in a population-based sample of adults with tuberous sclerosis. J Intellect Disabil Res 2006; 50 : 561-569.

[24] de Vries, P. J.: Neurodevelopmental, psychiatric and cognitive aspects of tuberous sclerosis complex. [in:] Tuberous Sclerosis Complex: Genes, 
Clinical Features and Therapeutics. Kwiatkowski, D. J., Whittemore, V.H., Thiele, E.A. [ed.], Wiley-Blackwell, Weinheim 2010.

[25] de Vries, P. J., Hunt, A., Bolton, P. F.: The psychopathologies of children and adolescents with tuberous sclerosis complex (TSC). Eur Child Adolesc Psychiatry 2007; 16: 16-24.

[26] Eden, K. E., de Vries, P. J., Moss, J., et al.: Self-injury and aggression in tuberous sclerosis complex: cross syndrome comparison and associated risk markers. J Neurodev Disord 2014; 6: 10.

[27] Staley, B. A., Montenegro, M. A., Major, P., et al.: Self-injurious behavior and tuberous sclerosis complex: frequency and possible associations in a population of 257 patients. Epilepsy Behav 2008; 13: 650-653.

[28] de Vries, P. J., Gardiner, J., Bolton, P. F.: Neuropsychological attention deficits in tuberous sclerosis complex (TSC). Am J Med Genet A 2009; 149A: 387-395.

[29] Ridler, K., Suckling, J., Higgins, N. J., et al.: Neuroanatomical correlates of memory deficits in tuberous sclerosis complex. Cereb Cortex 6; 17: 261-271.

[30] Whittemore, V. H., Lewis, J.: Impact of TSC on the family and genetic counseling issues. [in:] Tuberous Sclerosis Complex: Genes, Clinical Features and Therapeutics. Kwiatkowski D.J., Whittemore V.H., Thiele E.A., et al., Wiley-Blackwell, Weinheim 2010.
[31] de Vries, P. J., Howe, C. J.: The tuberous sclerosis complex proteins-a GRIPP on cognition and neurodevelopment. Trends Mol Med 2007; 13: 319-326.

[32] Goorden, S. M., van Woerden, G. M., van der Weerd, L., et al.: Cognitive deficits in Tsc1+/- mice in the absence of cerebral lesions and seizures. Ann Neurol 2007; 62: 648-655.

[33] Ehninger, D., Han, S., Shilyansky, C., et al.: Reversal of learning deficits in a Tsc2+/- mouse model of tuberous sclerosis. Nat Med 2008; 14: 843-848.

[34] De Vries, P. J., Whittemore, V. H., Leclezio, L., et al.: Tuberous sclerosis associated neuropsychiatric disorders (TAND) and the TAND Checklist. Pediatr Neurol 2015; 52: 25-35.

[35] Krueger, D. A., Northrup, H., Roberds, S., et al.: Tuberous sclerosis complex surveillance and management: recommendations of the 2012 International Tuberous Sclerosis Complex Consensus Conference. Pediatr Neurol 2013; 49: 255-265.

[36] Leclezio, L., Jansen, A., Whittemore, V. H., et al.: Pilot validation of the tuberous sclerosis-associated neuropsychiatric disorders (TAND) checklist. Pediatr Neurol 2015; 52: 16-24. 
